\title{
Treatment response to idelalisib in a patient with immunodeficiency-associated Burkitt lymphoma harboring a PIK3CA H1047R mutation
}

\author{
Annalen Bleckmann ${ }^{1,2}$. Sascha Dierks ${ }^{1}$. Hans-Ulrich Schildhaus ${ }^{3}$. Niels Hellige ${ }^{4}$. Ulrike Bacher ${ }^{1,5}$. \\ Lorenz Trümper ${ }^{1} \cdot$ Gerald Wulf $^{1}$
}

Received: 13 January 2020 / Accepted: 24 February 2020 / Published online: 20 March 2020

(C) The Author(s) 2020

Dear Editor,

While in Burkitt lymphoma (BL) immunochemotherapy readily induces remissions, the clinical outcomes for patients with refractory or recurrent disease are still adverse [1,2]. The phosphatidylinositol-3 kinase (PI3K) signal transduction pathway is involved in the activation, proliferation, and migration of B lymphocytes, and a cooperation of MYC and PI3K has been described in BL oncogenesis. Idelalisib is a highly selective inhibitor of the PI3K delta isoform [3] with significant clinical activity against indolent B cell lymphomas $[4,5]$. We here report the successful salvage therapy with idelalisib in a patient with relapsed immunodeficiency-associated BL exhibiting a TP53 mutation and a H1047R mutation in the PIK3CA gene.

The initial diagnosis of stage IIIB BL disease and concurrent HIV-1 positivity was made in a 65 -year-old male patient with multifocal lymphadenopathy and B-symptoms. The patient was started on immediate anti-viral therapy. At initial presentation, the patient appeared ineligible for multiphase leukemia-based regimens due to comorbidities (ischemic heart disease, impaired re-

Annalen Bleckmann

annalen.bleckmann@ukmuenster.de

1 Department of Haematology and Medical Oncology, University Medicine Göttingen, Göttingen, Germany

2 Department of Medicine A, Hematology, Oncology and Pneumology, University Hospital Münster, Münster, Germany

3 Department of Pathology, University Medicine Göttingen, Göttingen, Germany

4 Department of Radiology, University Medicine Göttingen, Göttingen, Germany

5 Department of Hematology and Central Hematology Laboratory, Inselspital, Bern University Hospital, University of Bern, Bern, Switzerland nal function), so that he received one course of R-CHOP, and upon adequate tolerance and response, further seven courses of R-CHOEP-21, inducing a complete remission. Ten months from initial diagnosis, relapse manifested as an isolated cutaneous manifestation $(3 \times 5 \mathrm{~cm})$ in the upper thigh. Two courses of platine/Ara-C-based chemotherapy (R-DHAP) induced partial remission, consolidated by involved site radiotherapy. Fifteen months after initial diagnosis the disease recurred again, at this time refractory to methotrexate/Ara-C-based chemotherapy (dexamethasone $20 \mathrm{mg}$ p.o., etoposide $60 \mathrm{mg} / \mathrm{m}^{2} \mathrm{~d} 4+5$ i.v., cytarabine $60 \mathrm{mg} / \mathrm{m}^{2} \mathrm{~d} 4+5$ i.v.; ifosfamide $400 \mathrm{mg} / \mathrm{m}^{2} \mathrm{~d} 1-5$ i.v.; methotrexate $500 \mathrm{mg} / \mathrm{m}^{2}$ i.v., methotrexate $12 \mathrm{mg}$ i.th. $\mathrm{d} 3$ ). Additional radiotherapy and vinblastine every other week was started in palliative intention. Responding to the patient's wish for further treatment, off-label idelalisib was initiated $(150 \mathrm{mg}$ bid) inducing shrinkage of the tumor (Fig. 1a, b) and decline of plasma LDH (Fig. 1c). Idelalisib was continued without infectious complications or adverse reactions for 10 months, until the tumor recurred and the patient succumbed to progressive disease.

Analysis of the initial lymphoma by high-throughput sequencing (HTS) detected a TP53 mutation $(T 175 H$, VAF $83.5 \%$ ), compatible with coincident structural loss of the second TP53 allele and presumably representing the major unfavorable molecular factor in this case [6-8]. In addition, we identified two mutations in the catalytic alpha subunit of the PIK3CA gene, i.e., p.H1047R (variant allele frequency (VAF) 5.0\%) and p.Q1033R (VAF 3.7\%) affecting exon 21 on the same allele. This PIK3CA H1047R mutation affects the highly conserved catalytic subunit p110a and has previously been identified at high frequency in many types of solid tumors $[9,10]$. In patients receiving PI3K/AKT/mTOR inhibitors, the presence of the PIK3CA H1047R mutation was associated with improved response rates compared with patients with wild-type PIK3CA or other PIK3CA mutations (38\% vs. $10 \%$ vs. $13 \%$ ) [11]. So far, PIK3CA H1047R mutations have not been described in BL cell 
Fig. 1 Pre-treatment MRI (a) demonstrates a well-defined slightly hyperintense soft tissue mass (arrow) between the musculus vastus medialis and the arteria femoralis superficialis on axial PD TSE FS transversal slices. At the 9-month MRI follow-up, (b) the tumor is no longer detectable, axial PD TSE FS transversal images showing posttherapeutic changes only. (c) Course of plasma LDH under idelalisib treatment plasma LDH levels as aggregated by routine laboratory monitored, local upper limit of normal (ULN) 256 [U/1] as indicated. Documentation starting (day 0) at 4 weeks after last prior treatment (radiotherapy), patient died on day $357(\dagger)$
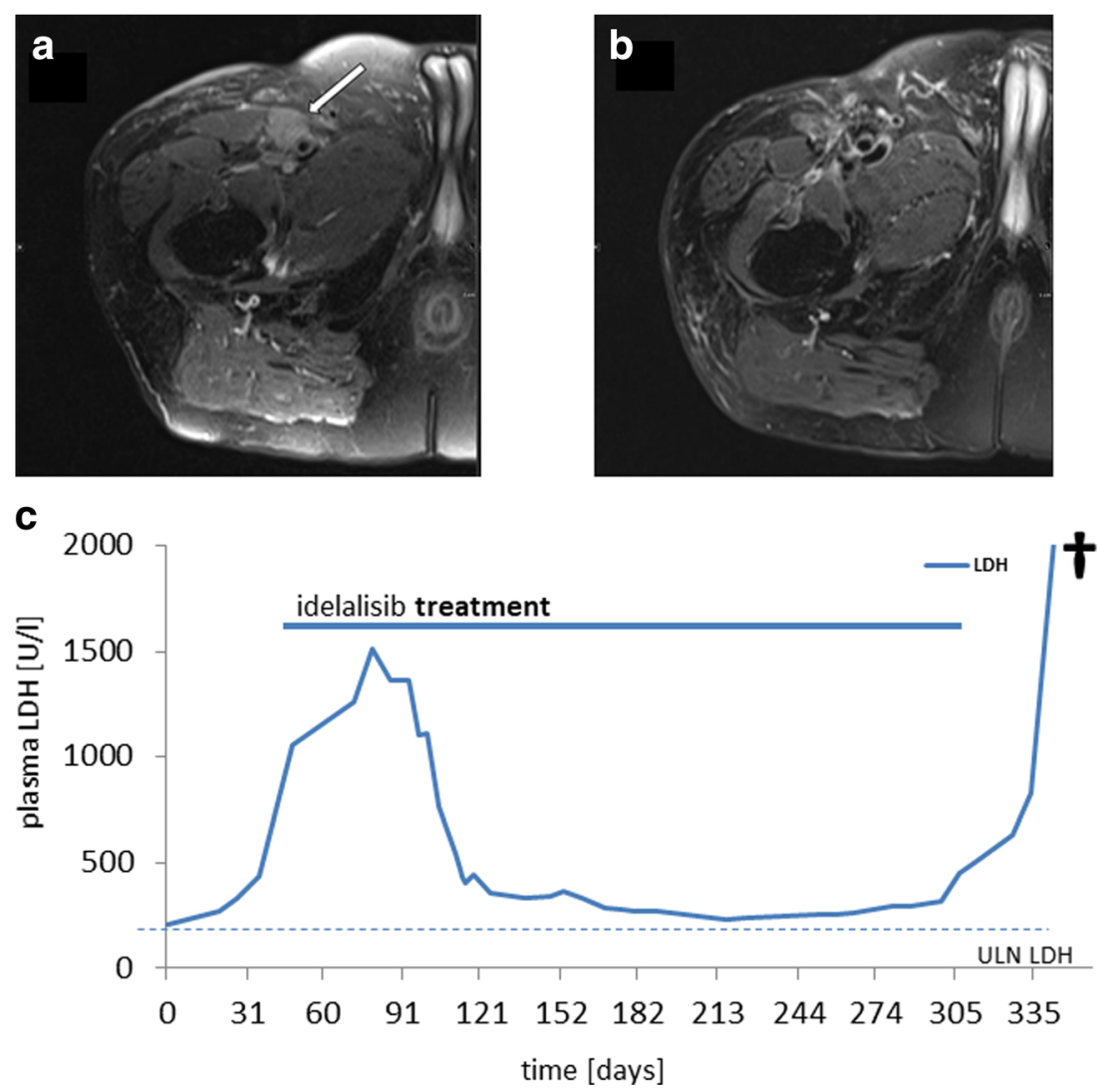

lines or primary tumor samples. However, preclinical evidence demonstrated that deregulated $M Y C$ and PI3K activity synergize in BL pathogenesis [8], and that pathway inhibitors suppress PI3K-dependent proliferation of human BL cells $[12,13]$. We speculate, that in the case of the index patient, the PIK3CA H1047R mutation was a lymphoma propagating factor by cooperation of MYC/IgH and PIK3CA [14].

In conclusion, our report supports further exploration of PI3K inhibition in the treatment of patients with refractory/ relapsed BL. Screening for PIK3CA mutations may allow the detection of specific lymphoma cell vulnerabilities for targeted therapy in relapsed/refractory disease.

Funding Information Open Access funding provided by Projekt DEAL.

\section{Compliance with ethical standards}

Informed consent Informed consent was obtained from all individual participants included in the study.

Open Access This article is licensed under a Creative Commons Attribution 4.0 International License, which permits use, sharing, adaptation, distribution and reproduction in any medium or format, as long as you give appropriate credit to the original author(s) and the source, provide a link to the Creative Commons licence, and indicate if changes were made. The images or other third party material in this article are included in the article's Creative Commons licence, unless indicated otherwise in a credit line to the material. If material is not included in the article's
Creative Commons licence and your intended use is not permitted by statutory regulation or exceeds the permitted use, you will need to obtain permission directly from the copyright holder. To view a copy of this licence, visit http://creativecommons.org/licenses/by/4.0/.

\section{References}

1. Molyneux EM, Rochford R, Griffin B, Newton R, Jackson G, Menon G, Harrison CJ, Israels T, Bailey S (2012) Burkitt's lymphoma. Lancet. 379(9822):1234-1244

2. Dunleavy K, Little RF, Wilson WH (2016) Update on Burkitt lymphoma. Hematol Oncol Clin North Am 30(6):1333-1343

3. Meadows SA, Vega F, Kashishian A et al (2012) PI3Kdelta inhibitor, GS-1101 (CAL-101), attenuates pathway signaling, induces apoptosis, and overcomes signals from the microenvironment in cellular models of Hodgkin lymphoma. Blood. 119(8):1897-1900

4. Graf SA, Gopal AK (2016) Idelalisib for the treatment of nonHodgkin lymphoma. Expert Opin Pharmacother 17(2):265-274

5. Davies A (2015) Idelalisib for relapsed/refractory indolent B-cell non-Hodgkin's lymphoma: an overview of pharmacokinetics and clinical trial outcomes. Expert Rev Hematol 8(5):581-593

6. Love C, Sun Z, Jima D et al (2012) The genetic landscape of mutations in Burkitt lymphoma. Nat Genet 44(12):1321-1325

7. Burmeister T, Schwartz S, Horst HA, Rieder H, Gökbuget N, Hoelzer D, Thiel E (2005) Molecular heterogeneity of sporadic adult Burkitt-type leukemia/lymphoma as revealed by PCR and cytogenetics: correlation with morphology, immunology and clinical features. Leukemia. 19(8):1391-1398 
8. Schmitz R, Ceribelli M, Pittaluga S, Wright G, Staudt LM (2014) Oncogenic mechanisms in Burkitt lymphoma. Cold Spring Harb Perspect Med 4(2)

9. Wan G, Pehlke C, Pepermans R, Cannon JL, Lidke D, Rajput A (2015) The H1047R point mutation in p110 alpha changes the morphology of human colon HCT116 cancer cells. Cell Death Discov 1:15044

10. Sheen MR, Marotti JD, Allegrezza MJ, Rutkowski M, ConejoGarcia JR, Fiering S (2016) Constitutively activated PI3K accelerates tumor initiation and modifies histopathology of breast cancer. Oncogenesis. 5(10):e267

11. Janku F, Wheler JJ, Naing A, Stepanek VM, Falchook GS, Fu S, Garrido-Laguna I, Tsimberidou AM, Piha-Paul SA, Moulder SL, Lee JJ, Luthra R, Hong DS, Kurzrock R (2012) PIK3CA mutations in advanced cancers: characteristics and outcomes. Oncotarget. 3(12): $1566-1575$
12. Curnock AP, Knox KA (1998) LY294002-mediated inhibition of phosphatidylinositol 3-kinase activity triggers growth inhibition and apoptosis in CD40-triggered Ramos-Burkitt lymphoma B cells. Cell Immunol 187(2):77-87

13. Spender LC, Inman GJ (2014) Developments in Burkitt's lymphoma: novel cooperations in oncogenic MYC signaling. Cancer Manag Res 6:27-38

14. Janku F, Wheler JJ, Naing A, Falchook GS, Hong DS, Stepanek VM, Fu S, Piha-Paul SA, Lee JJ, Luthra R, Tsimberidou AM, Kurzrock R (2013) PIK3CA mutation H1047R is associated with response to $\mathrm{PI} 3 \mathrm{~K} / \mathrm{AKT} / \mathrm{mTOR}$ signaling pathway inhibitors in early-phase clinical trials. Cancer Res 73(1):276-284

Publisher's note Springer Nature remains neutral with regard to jurisdictional claims in published maps and institutional affiliations. 